\title{
Alzheimer Hastalığının Tedavisinde Kullanılan İlaçlar ve Yeni Yaklaşımlar
}

\author{
Mevlüt Akdağ $^{1 *}$ D , Muhammed Ergün ${ }^{2}$, A.Berna Özçelik ${ }^{1}$, Mehtap Uysal ${ }^{1}$ \\ ${ }^{1}$ Farmasötik Kimya Anabilim Dalı, Eczacılık Fakültesi, Gazi Üniversitesi, 06330 Ankara, TÜRKIYE \\ ${ }^{2}$ Farmasötik Kimya Anabilim Dalı, Eczacılık Fakültesi, Cumhuriyet Üniversitesi, 58140 Sivas, TÜRKIYE
}

.Geliş / Received: 12/07/2019, Kabul / Accepted: 23/07/2019

\begin{abstract}
Öz
Demansların büyük çoğunluğundan sorumlu olan Alzheimer Hastalığı hızla yaşlanan nüfusla birlikte özellikle batı toplumlarında büyük bir sağlık sorunu haline gelmiştir. Hastalığın doğası tam olarak anlaşılamasa da çeşitli hipotezlere dayalı olarak ilaç geliştirme çalışmaları devam etmektedir. Mevcut ilaçlardan hiçbiri hastalığın ilerleyişini durduramamakta ya da geri çevirememektedir. Bu nedenle de hastalığın temelini hedef alan yeni ilaçlara büyük bir gereksinim vardır. Bu derlemede Alzheimer Hastalığı için mevcut olarak kullanılan ilaçlara ve yeni hedeflere yer verilmiştir. Bu kapsamda mevcut ilaçlar, amiloid hipotezini temel alan yaklaşımlar, tau hipotezini temel alan yaklaşımlar ve mikroglialar ile Alzheimer Hastalığı arasındaki ilişki incelenmiş, yeni hedeflere yönelik geliştirilen molekül örneklerine yer verilmiştir.

Anahtar Kelimeler: alzheimer, asetilkolin, amiloid, tau, mikroglia
\end{abstract}

\section{Drug Used in the Treatment of Alzheimer's Disease and New Approaches}

\begin{abstract}
Alzheimer's disease, which is responsible for the majority of the dementia cases, has become an important health problem especially in western countries due to the rapidly aging population. Though the nature of the disease has not been totally understood yet drug development studies continue based on various hypotheses. None of the current drugs can not stop or reverse the progress of the disease. In this review, current drugs and new targets are included. In this context, current drugs, approaches based on amiloid and tau hypotheses, and relationship between microglial cells and Alzheimer's disease are researched and molecul examples developed for new targets are included.
\end{abstract}

Keywords: alzheimer, acetylcholine, amiloid, tau, microglia

\section{Giriş}

Alzheimer hastalığı (AH), merkezi sinir sisteminin (MSS) nörodejeneratif bir hastalığıdır. Psikiyatrik olarak diğer bilişsel işlevlerin yanı sıra hafızanın ilerleyen bozuklukları ve günlük yaşamda artan bir özerklik kaybı ile karakterize edilmektedir (Müller vd.., 2019). Patofizyolojik olarak ise AH, MSS'de hiper-fosforile edilmiş tau ve beta-amiloid $(\mathrm{A} \beta)$ plaklarının birikmesi ile karakterize edilmiştir (Hawkins ve Duchen, 2019). Hastaların çoğunun patogenezinde A $\beta$ 'nin yetersiz şekilde uzaklaştırılması, aşırı $\mathrm{A} \beta$ üretiminden daha önemlidir. Bu durum $\mathrm{A} \beta$ klirensinin artırılması yaklaşımlarının tedavide önemli olabileceğini göstermektedir (Saito vd., 2019). AH gibi nörodejeneratif hastalıklarda sinaps kaybı ve sonrasinda nöronal ölümün en altında yatan mekanizma sinaptik kompartmanlarda lokal olarak ortaya çıkan apoptozisdir (Nonaka vd.,2019). 
Bununla birlikte, oluşan tau düğümleri ve $A \beta$ plaklarının hastalığın patofizyolojisini yönettiği mi yoksa AH'nin semptomu mu olduğu kesin değildir. AH'li kişilerin büyük çoğunluğunun 65 yaş ve üstü yaşta olduğu görülmektedir (Hawkins ve Duchen, 2019). Bu hastalık Dünya Sağlık Örgütü tarafından öncelikli bir küresel halk sağlığı problemi olarak kabul edilmektedir. AH'nin patogenezine ve hastalığın nasıl geliştiğine dair kazanımlarımızdaki büyük artışa rağmen, Alois Alzheimer, 1907'deki ilk vakayı rapor ettiğinden beri, hala hastalık-modifiye edici tedaviler tam olarak mevcut değildir (Lane vd., 2018). Tedavi önerilerinden birisi olan; bazal ön beyindeki kolinerjik nöronların seçici olarak kaybının ardından asetilkolinesteraz (AchE) inhibitörleri ile ilk 1980'lerde denenen tedavilerde, klinik iyileşmenin belgelenmesi "yaşa bağlı bilişsel işlev bozukluğunun kolinerjik hipotezi" ni desteklemiştir (Chen ve Mobley, 2019). Fakat bu yöntem tek başına kısmi semptomatik tedaviden ileriye gidememiştir.

Günümüzde sadece Amerika'da 5 milyondan fazla insan AH hastası olarak yaşamaktadır. $\mathrm{Bu}$ sayının eğer bir tedavi bulunmazsa 2050 y1lına kadar artan yaşlı nüfusla birlikte 13,8 milyona çıkacağı öngörülmektedir (Márquez ve Yassa, 2019). Başka bir araştırmada ise dünya çapında şu anda tahminen 44 milyon demanslı hastanın yaşadığı belirtilmektedir. Demansin en büyük nedeni olarak $\mathrm{AH}$ gösterilmektedir. Nüfus yaşlandıkça, bu sayının 2050 yılına kadar üç katından fazla olacağ1 öngörülmektedir ki bu durumda AH'nin ABD'ye maliyeti 600 milyar doları aşacaktır. İngiltere ve Galler'de, demanslar
2015 yılında kaydedilen tüm ölümlerin \% 11,6'sını oluşturmaktadır. Gelecek yıllarda, düşük ve orta gelirli ülkelerde görülen kardiyovasküler rahatsızlıklarda, diabette ve AH'de artışın demans prevalansında da olmas1 beklenmektedir. AH, demansl hastaların \%50-75 inde karakterizedir ve bu durum kabaca 65 yaşından sonra her 5 yılda bir ikiye katlanmaktadır (Lane vd., 2018).

Bununla birlikte yapılan araştırmalarda vasküler risk yönetimindeki son gelişmelerin, AH prevalansını başarıyla azalttığı belirtilmektedir. $\mathrm{Bu}$ nedenle günümüzde serebrovasküler hastalığın, AH patogenezinde hem doğrudan hem de dolaylı olarak yer aldığı kabul edilmektedir.

Tüm önerilen farklı hipotezler ve yapılan çalışmalar bize, AH'nin etkili tedavisi için çoklu tedavi yöntemleri kullanılması gerektiğini göstermektedir. Bu derlemede de bu yöntemlere yönelik yapılan araştırmalar ele alınmıştır.

\section{Alzheimer Kullanılan İlaçlar}

Tedavisinde

AH'yi durduran ya da geri çeviren bir ilaç günümüzde mevcut olmasa da FDA (U.S. Food and Drug Administration) onaylı AchE (Asetilkolin esteraz) inhibitörleri (rivastigmin, galantamin ve donepezil) ve bir N-metil-D-aspartat (NMDA) reseptör antagonisti olan memantin (Şekil 1), hastalığın semptomlarını gidermek amaciyla kullanılmaktadır. Bilişsel fonksiyonlarda bir artış sağladığı düşünülen bu ilaçların etkinliği ise tartışmalıdır (Herrmann vd., 2011). 


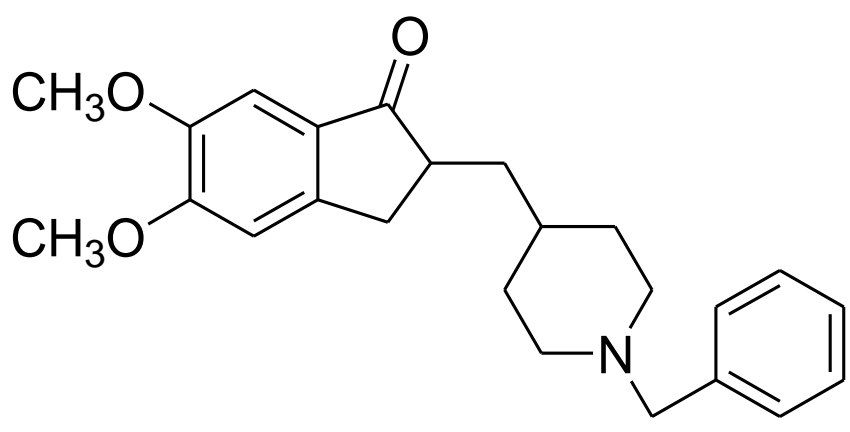

Donepezil<smiles>COc1ccc2c3c1O[C@H]1C[C@@H](O)C=C[C@@]31CCN(C)C2</smiles>

Galantamin<smiles>CCN(C)C(=O)Oc1cccc([C@@H](C)N(C)C)c1</smiles>

Rivastigmin

Memantin

Şekil 1. AchE inhibitörleri ve bir NMDA antagonisti olan memantin

Santral sinir sistemindeki kolinerjik nöron kaybı kognitif fonksiyonlardaki azalma ile ilişkilidir. AchE enzimi asetilkolini (Ach) parçalar ve sinaptik aralıkta birikmesini engeller. Bu nedenle AchE enzimini inhibe etmek kolinerjik sinapslarda Ach birikimine sebep olur ve kognitif fonksiyonlarda bir artış sağlaması beklenir (Colović vd., 2013).

Ligandlar AchE enziminin aktif yöresine ulaşabilmek için enzimin üst kısmında bulunan dar bir boğazdan geçmek zorundadir (Radic ve Taylor, 2001). Enzimin geçit bölgesindeki amino asitler aromatik yapılarla etkileşmede önemlidir. Ligandların enzime bağlanmalarında pozitif bir yük taşımaları önemlidir (Axelsen vd., 1994).
Düşük afiniteli bir NMDA reseptör antagonisti olan memantinin AchE inhibitörü donepezil ile kombine kullanımının kognitif fonksiyonlarda bir yarar sağladığı görülmüştür. Nöronlarda eksitoksisiteyi engellediği düşünülen bu ajanın nörodejenerasyonu engellediğine dair bir kanıt bulunmamaktadır (Marum, 2009 ).

\section{Alzheimer Tedavisindeki Yaklaşımlar}

Hastalığının Yeni

Hastalığın ilerleyişini durduran ya da tersine çeviren bir tedavinin bulunmamasindan ötürü son yıllarda özellikle hastalığın ilerleyişini durdurmak amaciyla amiloid ve tau hipotezini temel alan ilaçlar üzerinde yapılan çalışmalar 
yoğunlaşmıştır. Bunun yanı sıra semptomatik fayda sağlayabileceği düşünülen yeni ajanlar için de klinik çalışmalar devam etmektedir.

\section{$3.1 \alpha 7-n i k o t i n i k$ asetilkolin reseptör agonistleri}

Semptomatik AH tedavisinde yeni bir hedef $\alpha 7$-nikotinik asetilkolin reseptörleridir $(\alpha 7 \mathrm{nAchR}) . \quad \mathrm{Bu}$ reseptörler kognitif fonksiyonlarla ilişkilidir ve bu nedenle de semptomatik $\mathrm{AH}$ tedavisinde önemli bir ilaç hedefi haline gelmişlerdir. Aynı zamanda $A \beta$ peptitlerin bu reseptörlere karşı yüksek afinite gösterdiğini ortaya koyan çalışmalar vardır (Wallace ve Porter , 2011; Liu vd., 2001).

$\mathrm{Bu}$ reseptörler için anabasein, anabasin ve nikotin gibi (Şekil 2) alkaloidlerden hareketle bu grubun ilk bileşikleri tasarlanmış ve sonrasında da $\mathrm{AH}$ tedavisinde fayda sağlayabileceği düşünülen birkaç agonist klinik denemelere girmiştir (Hashimoto vd., 2005).

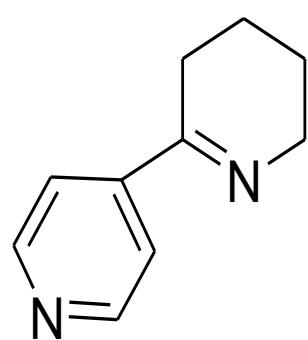

Anabasein<smiles>c1cncc(C2CCCCN2)c1</smiles>

Anabasin (Neonikotin)<smiles>c1cncc([C@H]2CCCN2)c1</smiles>

Nikotin

Şekil 2. $\alpha 7 \mathrm{nAchR}$ agonisti doğal bileşikler

Klinik denemelere giren ve oral aktif bir ajan olan Encenicline (EVP-6124) (Şekil 3) nanomolar konsantrasyonlarda prokognitif etkiler gösteren bir $\alpha 7 \mathrm{nAchR}$ agonistidir. Tamamlanan faz II çalışmalarında klinik olarak herhangi bir güvenlik veya tolere edilebilirlik sorunu gözlenmemiş ve bellek performansını artırmıştır fakat faz III aşamasına gelindiğinde ciddi gastrointestinal sistem (GIS) yan etkileri sebebiyle klinik çalışmaları durdurulmuştur (Lao vd., 2019).<smiles>O=C(N[C@@H]1CN2CCC1CC2)c1cc2cccc(Cl)c2s1</smiles>

Encenicline

\subsection{Amiloid hipotezini temel alan ilaçlar}

Son y1llarda amiloid hipotezini temel alan birçok ajan klinik denemelere girmiştir. Amiloid prokürsör proteininin (APP) sırasıyla $\beta$-sekretaz (BACE) ve $\gamma$-sekretaz ile klevaj olması sonucu $A \beta$ peptitler oluşur (Murphy ve LeVine, 2010 ). Bu nedenle de bu iki enzimin bir ilaç hedefi haline gelmesi beklenen bir durumdur. Aynı zamanda ileri glikasyon son ürünlerinin bir reseptörü olan RAGE (reseptor for advanced glycation end products) $A \beta$ peptitlerin inflaksını sağlayan bir reseptördür ve bu reseptörleri inhibe etmek de bir strateji olarak karşımıza çıkmaktadır (Bongarzone vd., 2017).

Şekil 3.Klinik denemelere girmiş $\alpha$ 7nAchR agonisti EVP-6124 (encenicline) 


\subsubsection{BACE inhibitörleri}

BACE inhibisyonunu hedef alan ilk moleküller düşük oral biyoyaralanım, kan beyin bariyeri penetrasyonu, karaciğer toksisitesi gibi sebeplerden ötürü başarısız olmuştur (Lao vd., 2019).

Bir aminotiyodiazindioksit türevi olan verubecestat (MK-8931) (Şekil 4) BACE-1 ve BACE-2 için potent bir inhibitör olarak bulunmuştur. Bir aspartil proteaz olan BACE-1'in katalitik diyadı ile hidrojen bağı yapabilen isotiyoürelerden hareketle hazırlanmış olan bu bileşik farelerde ve primatlarda plak oluşumunu engellese de faz III aşamasına gelindiğinde istenilen klinik etkiyi sağlayamadığı için çalışmalar durdurulmuştur (Scott vd., 2016; Egan vd., 2019 ).<smiles>C[C@]1(c2cc(NC(=O)c3ccc(F)nc3)ccc2F)CS(=O)(=O)NC(=N)N1</smiles>

Verubecestat

Şekil 4. Klinik denemelere girmiş BACE inhibitörü MK-8931 (verubecestat)

\subsection{2. $\gamma$-sekretaz inhibitörleri ve modülatörleri}

BACE'den sonra ikinci bir hedef olarak karşımıza $\gamma$-sekretaz inhibisyonu çıkmaktadır.Bu enzimin APP dışında birçok substratının olması ve bu hedefi inhibe eden moleküllerin hücreler için yaşamsal bir önem taşıyan notch sinyalini bozmasindan ötürü bu hedefe karş1 geliştirilen inhibitörlerin çok fazla istenmeyen yan etkisi bulunmaktadır
(Olsauskas-Kuprys vd., 2013.).Bunlardan en ilginç olanı ise bu inhibitörlerin Alzheimer hastalarında yan etki olarak öğrenme güçlüğü çıkarabilmesidir ki bu AH tedavisinde kabul edilebilir bir yan etki değildir (Strooper, 2014). Şekil 5'de bazı inhibitörlerin kimyasal yapısı gösterilmiştir.<smiles>CC(C)[C@H](O)C(=O)N[C@@H](C)C(=O)N[C@H]1C(=O)N(C)CCc2ccccc21</smiles>

Semagecestat<smiles>O=S(=O)(N[C@H](CO)C(F)(F)F)c1ccc(Cl)s1</smiles>

Begacestat<smiles>CCC[C@H](NC1CCc2cc(F)cc(F)c2C1)C(=O)Nc1cn(C(C)(C)CNCC(C)(C)C)cn1</smiles>

PF-3084014<smiles>NC(=O)C(CCC(F)(F)F)N(Cc1ccc(-c2ncon2)cc1F)S(=O)(=O)c1ccc(Cl)cc1</smiles>

BMS-708163

Şekil 5. Bazı $\gamma$-sekretaz inhibitörlerinin kimyasal yapısı 
$\gamma$-sekretaz inhibitörlerinin bu istenmeyen yan etkilerinden ötürü güvenlik profilinin artırıldığı $\gamma$-sekretaz modülatörleri denilen yeni bir grup bileşik geliştirilmiş ve bu bileşikler için hareket noktası notch sinyalini etkilemediği bilinen non-steroidal antiinflamatuar ilaçlar (NSAIII) olmuştur (Wolfe, 2008).

$\gamma$-sekretaz modülatörlerinin en bilinen örneklerinden biri olan tarenflurbil (şekil 6), flurbiprofenin $\mathrm{R}$ izomeridir ve siklooksijenaz (COX) inhibitörü aktivitesinden yoksundur (Weggen vd., 2007). COX aktivitesi göstermemesi GIS yan etkilerinden kaçınmayı sağlamıştır fakat tüm bu üstünlüklerine rağmen bileşiğin potensinin düşük olması ve kan beyin bariyerine iyi penetre olamamasından ötürü klinikte istenilen başarı elde edilememiştir (Imbimbo, 2009).<smiles>C[C@@H](C(=O)O)c1ccc(-c2ccccc2)c(F)c1</smiles>

Tarenflurbil (R-flurbiprofen)

Şekil 6. Bir $\gamma$-sekretaz inibitörü olan NSAIII yapısındaki bileşik tarenflurbil

\subsubsection{RAGE inhibitörleri}

RAGE doğal olarak birçok ligand 1 bağlayabilen bir transmembran zar proteinidir. $\mathrm{A} \beta$ peptitler de bu ligandlar arasindadir ve bu nedenle de bu reseseptörleri inhibe edebilecek ajanlar AH'nin tedavisinde yarar sağlayabilir. Bu reseptörün aktive olması aynı zamanda inflamatuar yanıtlarla da ilişkilidir (Kierdorf ve Fritz, 2013).

RAGE'nin bilinen çoğu ligandlarının protein yapıda olması (ileri glikasyon son ürünleri hariç) araştırmacıları küçük molekül keşfinden ziyade protein yapıda olan antikorlara yönlendirmiştir. İleri glikasyon son ürünlerinin yapısına bakıldığında (Şekil 7) bir N-heterosiklik halka kalıntısı ve amino asit kalıntıları içerdiği görülür. Bu da küçük molekül keşfinde hazırlanan ligandlar için bir başlangıç noktası sağlamaktadır (Han vd., 2012).

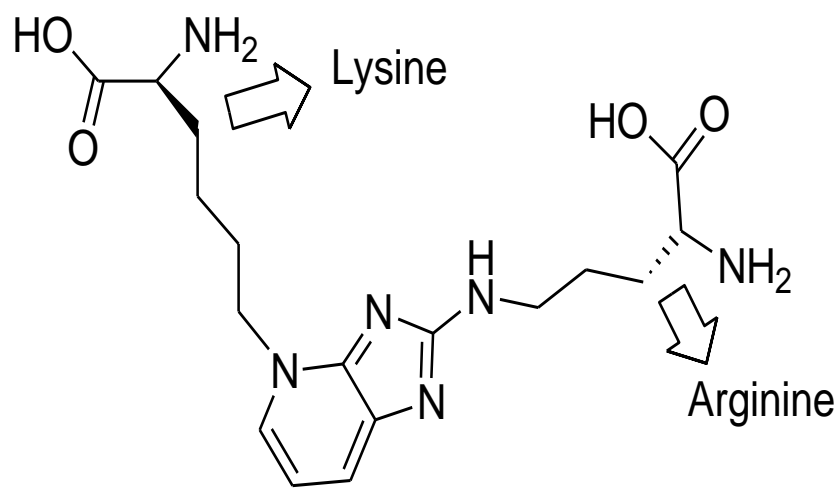

Pentosidin<smiles>Cc1nc(NCCC[C@H](N)C(=O)O)nc(C)c1O</smiles>

Argprimidin

Şekil 7. İleri glikasyon son ürünü olan pentosidin ve argprimidin

Bir RAGE inhibitörü olan azeliragon hem diyabetik nöropati hem de $\mathrm{AH}$ için klinik denemelere girmiş fakat çalışmalar faz III aşamasında durdurulmuştur (Şekil 8) (Bendlin, 2019.). 


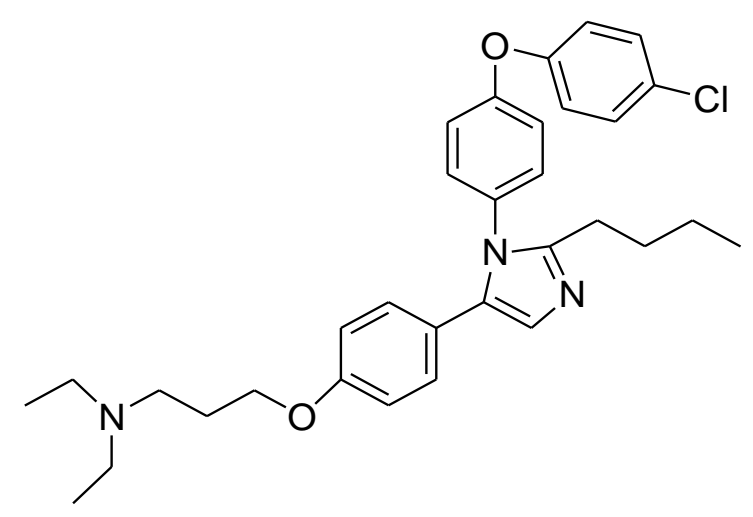

Azeliragon

Şekil 8. Klinik denemelere girmiş bir RAGE inhibitörü, azeliragon

\subsection{Tau hipotezini temel alan ilaçlar}

Tau hipotezini temel alan ilaçlar $\mathrm{A} \beta$ oluşumunu hedef alanlara göre daha başlangıç aşamasındadır.

Tau mikrotübüllere bağlı halde bulunarak onları stabilize eder ve nöronal transportu kolaylaştırır. AH'de tau mikrotübüllerden ayrışır ve dügüüler halinde agrege olur. Mikrotübül ve tau ayrışması sonucu nöronal transport inhibe olur (Grundke-Iqbal, 1986).

Taufosforilasyonu, taupatinin en kritik evrelerinden biri gibi görünmektedir. $\mathrm{Bu}$ sebeple tau hiperfosforilasyonu ve defosforilasyonunda rol oynayan enzimler anti-tau terapisi için hedef olabilir ( $\underline{\mathrm{Li}}$ ve Götz, 2017).

Tau fosforilasyonu değişik kinazlar ve fosfatazlarla kontrol edilir. Bunların arasında taufosforilasyonunu düzenleyen ana hedef glikojen sentaz kinaz $3 \beta$ 'dir (GSK-3 $\beta$ ). Tideglusib faz II aşamasında olan tek GSK-3 $\beta$ inhibitörüdür (Şekil 9) fakat klinik bir yarar gösterememiştir (Lao vd., 2019).

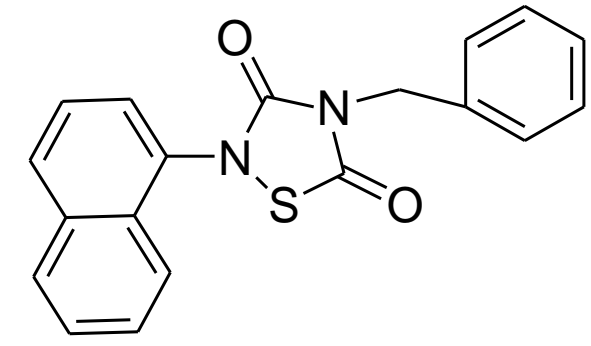

Tideglusib

Şekil 9. GSK-3 $\beta$ inhibitörü tideglusib

\subsubsection{Mikrotübül Stabilize Edici Ajalar}

Mikrotübül stabilize edici ajanların da $\mathrm{AH}$ tedavisinde klinik yarar sağlayabileceği düşünülmektedir. Paklitaksel (Şekil 10) toksik yan etkilerinden dolay1 kullanılamamaktadır fakat bir taksan türevi olan ve kan beyin bariyeri (KBB) penetrasyonu iyi olan TPI 287'nin (Şekil 10) AH için klinik çalışmaları başlatılmıştır (Anand ve Sabbagh, 2015).

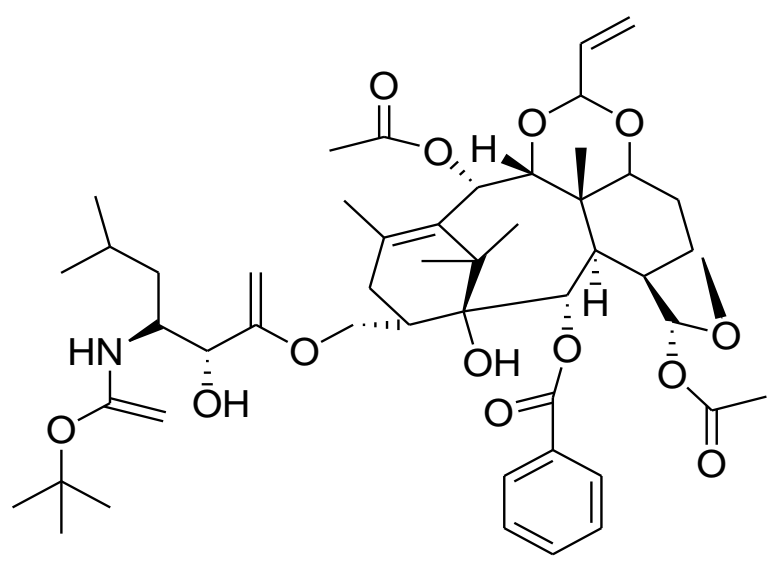

TPI 287

Şekil 10. Mikrotübül stabilize edici bir ajan olan taksan türevi TPI 287

\subsubsection{Tau agregasyon inhibitörleri}

Metiltiyoninyum (MT) tau agregasyon inhibitörlerinin ilk jenerasyonudur ve okside ve redükte formları bir denge halinde 
bulunur. Okside formu daha kararlıdır. Okside formun klorür tuzuna metilen mavisi denmektedir. Çözünürlük ve absorpsiyon bakımından farmakokinetik sınırlamaları olan bu molekülden hareketle ikinci jenerasyon bir inhibitör olan TRx0237 (Şekil 11) geliştirilmiştir. 2016 yılında tamamlanan faz III çalışmalarının sonucuna göre bileşik hafif-orta şiddetli $\mathrm{AH}$ hastalarında yararsız bulunmuştur (Baddeley vd., 2015) .<smiles>C[NH+](C)c1ccc2c(c1)Sc1cc([NH+](C)C)ccc1N2</smiles><smiles>CS(=O)(=O)[O-]</smiles>

TRx0237

Şekil 11.Tau agregasyon inhibitörü TRx07

\subsection{Mikroglialar ve Alzheimer hastalığ}

Mikroglialar MSS'nin immün hücreleridir. Mikroglia aracılı inflamasyon AH'de dahil birçok nörodejeneratif hastalığın ortak özelliğidir. Mikroglial hücreler M1 (proinflamatuar) ve M2 (antiinflamatuar) olmak üzere iki fenotip sergilerler. $\mathrm{Bu}$ fenotipler çevresel faktörlerle indüklenebilmektedir.LPS

(lipopolisakkarit) ve IFN- $\gamma$ (interferon- $\gamma$ ) ile indüklenebilen M1 hücrelerinde nitrikoksit sentaz ve TNF- $\alpha$, IL-1 $\beta$ gibi proinflamatuarlar ekspres edilir (Song ve Suk, 2017).

Çeşitli reseptörler ve sinyal moleküllerinin M1-M2 dönüşümünde rol oynadıkları
bilinmektedir.Nükleer reseptörler [peroksizom proliferator aktifleştirici reseptör (PPAR) $\gamma$, PPAR $\delta$, retinoid $\mathrm{X}$ reseptör (RXR)], redoks sinyal molekülleri [ nikotinamid adenin dinükleotid fosfat oksidaz 2 (NOX2), Hipoksi ile

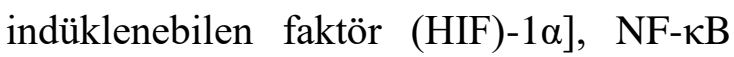
(nükleer faktör kapa $\mathrm{B}$ ) sinyal molekülleri ve metabolik değişime aracı proteinlerin mikroglia dönüşümünde önemli oldukları görülmüştür (Song ve Suk , 2017).

Bir PPAR- $\gamma$ agonisti olan pioglitazon (Şekil 12) ile tedavinin farelerde M1-M2 değişimini sağladığı ve $A \beta$ miktarını azalttığ1 görülmüştür (Song ve Suk , 2017).

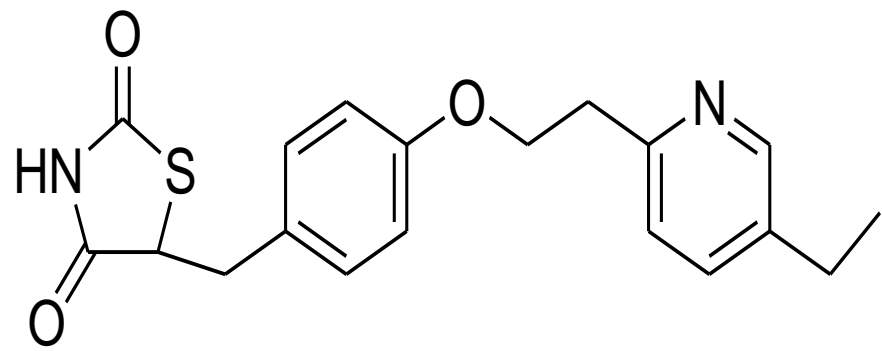

Pioglitazon

Şekil 12. PPAR- $\gamma$ agonisti pioglitazon

NADPH (nikotinamid adenin dinükleotid fosfat) oksidaz (NOX) ailesi intrasellüler NADPH/NADH'1 okside eder ve bu da moleküler oksijenin süperoksite dönüşümünü sağlar. $\mathrm{Bu}$ nedenle NOX inhibisyonu nörodejeneratif hastalıklarda potansiyel bir hedeftir (Surrace ve Block, 2012).

Direkt NOX inhbisyonu yapan moleküller (opioidler gibi) bulunsa da bunların yeterince selektif olmamasi ve opioid benzeri yapıların bazılarının agonist bazılarının antagonist olarak davranması tedavide kullanılmalarını kısıtlamaktadır (Surrace ve Block, 2012). 
Farelere uygulanan 9 aylık ibuprofen (Şekil 13) tedavisi, (COX2 inhibisyonundan bağımsız olarak) NOX2 kompleksinin birleşmesini inhibe ederek kognitif fonksiyonlarda iyileşme yapmadan oksidatif stresi ve plak yükünü azaltmıştır (Surrace ve Block, 2012).<smiles>CC(C)Cc1ccc(C(C)C(=O)O)cc1</smiles>

İbuprofen

Şekil 13. NOX inhibisyonu yapan bir NSAIII, ibuprofen

Beyinde mikroglial hücrelerde de bulunan kannabinoid tip 2 reseptörleri (CBR2) antiinflamatuar mekanizmalarla ilişkilendirilmiş ve bu sayede nörodejeneratif hastalıkların tedavisinde potansiyel bir hedef haline gelmişlerdir (Tanveer vd., 2012). NTRX-07 isimli biyoteknolojik bir CBR2 agonisti olan ilaç 2015 yilında NeuroTherapia tarafindan geliştirilmiş ve preklinik aşamada olumlu sonuçlar vermiştir.

\section{Sonuç ve Tartışma}

$\mathrm{AH}$ için ilaç geliştirme çalışmaları hızla devam etmektedir. Fakat hem MSS'ye ilaç geçişinin zor olmasından hem de AH'nin karmaşık doğasından ötürü 2002-2012 y1lları arasında \%99.6 gibi çok yüksek bir başarısızlı oranı söz konusudur (Cummings vd., 2014). Bu oran günümüzde daha iyi değildir.

Hastalığın semptomlarını gideren mevcut ilaçlara ek olarak hastalığın temelini hedef almaya yönelik ilaçlar geliştirilmeye çalışılmaktadır. Amiloid ve tau hipotezini temel alan bu ilaçların klinikte bir fayda sağlayamamaları bu hipotezlerin geçerliliğinin sorgulanmasına sebep olmaktadir.

Sonuç olarak, hipotez temelli geliştirilen çeşitli bileşiklerle AH tedavisi için bütüncül bir yaklaşım sergilenememektedir. AH'nin temeline yönelik araştırmalar yapıldıkça ve bu konudaki bilgi birikimimiz arttıkça yeni hedeflerin bulunması ve yeni ilaçların geliştirilmesi kaçınılmaz olacaktır.

\section{Kaynaklar}

Anand K, Sabbagh M., 2015. "Early investigational drugs targeting tau protein for the treatment of Alzheimer's disease" . Expert Opin Investig Drugs 24(10):13551360.

Axelsen P.H., Harel M., Silman I., Sussman J.L., 1994. "Structure and Dynamics of the active site gorge of acetylcholineesterase: synergistic use of molecular Dynamics simulation and X-ray crystallography"Protein Sci. 3(2): 188-197.

Baddeley T.C., McCaffrey J., Storey J.M.D., Cheung J.K.S., Melis V., Horsley D., Harrington C.R., Wischik C.M., 2015. "Complex Disposition of Methylthioninium Redox Forms Determines Efficacy in Tau Aggregation Inhibitor Therapy for Alzheimer's Disease" J Pharmacol Exp Ther 352:110-118.

Bendlin B.B., 2019. "Antidiabetic therapies and Alzheimer disease" DIALOGUESIN CLINICAL NEUROSCIENCE 21(1); 8391.

Bongarzone S., Savickas V., Luzi F., Gee A.D., 2017. "Targeting the Receptor for Advanced Glycation Endproducts (RAGE): A Medicinal Chemistry Perspective". $J$ Med Chem. 60(17):7213-7232. 
Chen X.Q., Mobley W.C. 2019. "Exploring the Pathogenesis of Alzheimer Disease in Basal For Brain Cholinergic Neurons: Converging Insights From Alternative Hypotheses" Front Neurosci. 7;13:446.

Colović M.B., Krstić D.Z., Lazarević-Pašti T.D., Bondžić A.M., Vasić V.M., 2013. "Acetylcholinesterase inhibitors: pharmacology and toxicology" Curr Neuropharmacol. 11(3):315-335.

Cummings JL, Morstorf T, Zhong K, 2014. "Alzheimer's disease drug-development pipeline: few candidates, frequent failures"Alzheimers Res Ther. 6(4):37.

Egan F.M., Kost J., Voss T., Mukai Y., Aisen P.S., Cummings J.L., Tariot P.N., Vellas B., Dyck C.H.V., Boada M., Zhang Y., Li W., Furtek C., Mahoney E., Mozley L.H., Mo Y., Sur C., Michelson D., 2019. "Randomized Trial of Verubecestat for Prodromal Alzheimer's Disease" N Engl J Med 380:1408-20.

Grundke-Iqbal I., Iqbal K.,Tung Y.C.,Quinlan M., Wisniewski H.M.,Binder L.I., 1986. "Abnormal phosphorylation of the microtubule-associated protein $\tau$ (tau) in Alzheimer cytoskeletal pathology" Proc. Natl. Acad. Sci.83, 4913-4917.

Han Y.T., Choi G.I., Son D., Kim N.J., Yun H., Lee S., Chang D.J., Hong H.S., Kim H., Ha H.J., Kim Y.H., Park H.J., Lee J., Suh Y.G., 2012." Ligand-Based Design, Synthesis, and Biological Evaluation of 2Aminopyrimidines, a Novel Series of Receptor for Advanced Glycation End Products (RAGE) Inhibitors "J. Med. Chem., 55 (21), 9120-9135.

Hashimoto K., Koike K., Shimizu E., Iyo M., 2005. “ $\alpha 7$ Nicotinic Receptor Agonists as Potential Therapeutic Drugs for Schizophrenia" Curr. Med. Chem. Central Nervous System Agents. 5. 171-184.

Hawkins K.E, Duchen M., 2019. "Modelling mitochondrial dysfunction in
Alzheimer's disease using human induced pluripotent stem cells" World J Stem Cells. 11(5): 236-253.

Herrmann N., Chau SA., Kircanski I., Lanctôt K.L., 2011. "Current and Emerging Drug Treatment Options for Alzheimer's Disease A Systematic Review" Drugs 71 (15): 2031-2065.

Imbimbo B.P., 2009. "Why did tarenflurbil fail in Alzheimer's disease?" J Alzheimers Dis. 17(4):757-60.

Kierdorf K., Fritz G., 2013. "RAGE regulation and signaling in inflammation and beyond"J Leukoc Biol. 94(1):55-68.

Lane C.A., Hardy J., Schott J.M., 2018. "Alzheimer's disease" Eur J Neurol. 25(1):59-70.

Lao K., Ji N., Zhang X., Qiao W., Tang Z., Gou X., 2019" Drug development for Alzheimer's disease: review" Journal of Drug Targeting, 27:2, 164-173.

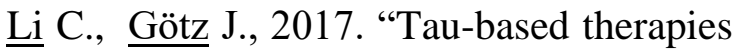
in neurodegeneration: opportunities and challenges" Nature Reviews Drug Discovery 16, 863-883.

Liu Q., Kawai H., Berg D.K., 2001.“betaAmyloid peptide blocks the response of alpha 7-containing nicotinic receptors on hippocampal neurons"Proc Natl Acad Sci USA, 98, 4734-4739.

Márquez F., Yassa M.A., 2019. "Neuroimaging Biomarkers for Alzheimer's Disease" $\mathrm{Mol}$ Neurodegener. 7;14(1):21.

Marum, R.J.V., 2009. "Update on the use of memantine in Alzheimer's disease"Neuropsychiatr Dis Treat. 2009; 5: 237-247.

Murphy MP, LeVine H 3rd., 2010. "Alzheimer's disease and the amyloid-beta peptide". J Alzheimers Dis. 19(1):311-323. 
Müller P, Fendt M, Müller NG 2019. “Drug treatment of Alzheimer's dementia : Status quo and perspectives" Internist (Berl).doi: 10.1007/s00108-019-0625-4.

Nonaka S., Nakanishi H., 2019. "Microglial clearance of focal apoptotic synapses" Neurosci Lett. 5:134317.

Olsauskas-Kuprys R, Zlobin A, Osipo C., 2013. "Gamma secretase inhibitors of Notch signaling”. Onco Targets Ther. 6:943-955.

Radic Z., Taylor P., 2001. "Peripheral Site Ligands Accelerate Inhibition of Acetylcholinesterase by Neutral Organophosphates" J. Appl. Toxicol. 21, 13-14.

Saito S., Yamamoto Y., Ihara M., 2019. "Development of a Multicomponent Intervention to Prevent Alzheimer's Disease" Front Neurol. 8;10:490.

Scott J.D., Li S.W., Brunskill A.P.J., Chen X., Cox K., Cumming J.N., Forman M., Gilbert E.J., Hodgson R.A., Hyde L.A., Jiang Q., Iserloh U., Kazakevich I., Kuvelkar R., Mei H., Meredith J., Misiaszek J., Orth P., Rossiter L.M., Slater M., Stone J., Strickland C.O., Voigt J.H., Wang G., Wang H., Wu Y., Greenlee W.J., Parker E.M., Kennedy M.E., Stamford A.W., 2016. "Discovery of the 3-Imino1,2,4-thiadiazinane 1,1-Dioxide Derivative Verubecestat $\quad$ (MK-8931)-A $\quad \beta$-Site Amyloid Precursor Protein Cleaving Enzyme 1 Inhibitor for the Treatment of Alzheimer's Disease" Journal of Medicinal Chemistry 59 (23), 10435-10450.

Song GJ., Suk K., 2017. "Pharmacological Modulation of Functional Phenotypes of Microglia in Neurodegenerative Diseases"Front Aging Neurosci 9: 139. doi: 10.3389/fnagi.2017.00139.

Strooper B.D., 2014. " Lessons from a Failed $\gamma$-Secretase Alzheimer Trial"Cell. 159(4), 721-726.
Surrace M., Block M., 2012. "Targeting Microglia-Mediated Neurotoxicity: The Potential of NOX2 Inhibitors" Cell Mol Life Sci. 69(14): 2409-2427.

Tanveer R., McGuinness N., Daniel S., Campbell A.G.V.A., 2012. "Cannabinoid receptors and neurodegenerative diseases" WIREs Membr Transp Signal 1:633-639.

Wallace T.L., Porter R.H.P., 2011. "Targeting the nicotinic alpha7 acetylcholine receptor to enhance cognitionin disease" Biochemical Pharmacology 82 891-903.

Weggen S., Rogers M., Eriksen J., 2007. "NSAIDs: small molecules for prevention of Alzheimer's disease orprecursors for future drug development?" TRENDS in Pharmacological Sciences 28(10), 536543.

Wolfe M.S., 2008. "Inhibition and modulation of $\gamma$-secretase for Alzheimer's disease" Neurotherapeutics 5(3): 391398. 